\title{
ECOLOGICAL INVESTIGATION OF THE TINTINNID COMMUNITY ALONG THE COASTAL WATERS OF ALEXANDRIA, EGYPT
}

\author{
Nehad M. Nour El-Din \\ Oceanography Department, Faculty of Science, Alexandria University, \\ Moharem Bey 21511, Alexandria, Egypt.
}

Key words: Ecology, tintinnids, protozooplankton, coastal waters, Alexandria.

\section{ABSTRACT}

The distribution of the tintinnid assemblages was studied in samples collected from 2 areas subjected to primary treated sewage flow and agricultural/industrial mixed discharge along the coastal water of Alexandria during summer 1999 and winter 2000. During the entire investigation, the protozooplankton were numerically dominated by tintinnids with densities ranging between 26 and $9464 \mathrm{Ind} . / \mathrm{m}^{3}$. Distinct differences that appeared in the patterns of occurrence and numbers of the tintinnids in those locations, were attributed to different physical and chemical conditions.

Tintinnid assemblages were represented by 19 species, the most dominant of which were: Tintinnopsis beroidea, Favella ehrenbergii, Eutintinnus macilentus and Tintinnopsis campanula. Two freshwater tintinnids appeared at the near-shore locations of El-Mex Bay during high flow when salinity reached 9 psu.

\section{INTRODUCTION}

Protozooplankton constitute a significant proportion of total zooplankton biomass in a variety of aquatic environments (Mazumder et al., 1990). Studies of the distributional patterns of these smaller consumers and their spatial and temporal relationships with major hydrological features along the coastal water of Alexandria were studied by Hussein (1977); Dowidar et al . (1983); Aboul Ezz et al. (1990); Abdel-Aziz (1997) and Hussein (1997).

Probably the most important protozoans in all aquatic ecosystems are tintinnids, which are the major consumers of 
phytoplankton. Despite their obvious importance, they have received less attention due to their small size and consequent difficulties of identification and enumeration.

The aim of this work is to present an analysis of the species composition of tintinnids' abundance along Alexandria coast and to assess the impact of different environmental factors on their distributional pattern.

\section{STIDY AREA:}

Mex Bay is located to the west of Alexandria city, occupying an area of $19.4 \mathrm{Km}^{2}$ with a mean depth of $10 \mathrm{~m}$ (maximum depth $18 \mathrm{~m}$ ) yielding a water volume of $190 \times 10^{6} \mathrm{~m}^{3}$. The body receives approx. $2.4 \times 10^{9} \mathrm{~m}^{3} / \mathrm{y}$ of brackish water from Maruit Lagoon via the Ummum Drain, through the Mex Pump Station. In addition, the Bay receives $1.13 \times 10^{6} \mathrm{~m}^{3} / \mathrm{y}$ from the Western Harbor of Alexandria. The maximum flow through the Ummum Drain is usually approached during winter $\left(304 \times 10^{6} \mathrm{~m}^{3} /\right.$ month), while the minimum $\left(168 \times 10^{6} \mathrm{~m}^{3} / \mathrm{y}\right)$ is recorded during summer (Abdel-Moati, 1998).

A considerable amount of Alexandria's untreated domestic sewage is discharged into the coastal waters through a major outfall (Kayet Bay Pump Station) i.e. $>0.5 \times 10^{6} \mathrm{~m}^{3} / \mathrm{d}$ (Aboul-Kassim et al., 1992). This outfall discharge is at a distance of $670 \mathrm{~m}$ underwater outside the Eastern Harbor and east of Al-Anfoushi Bay. The discharge from the pipeline is variable with the maximum during summer, matching the increase in sewage load.

\section{SAMPLING:}

During the summer (July) of 1999 and winter (February) of 2000, zooplankton samples were collected from 2 transects perpendicular to the coastline (Fig. 1). These transects were located opposite to the Ummum Drain in El-Mex Bay (UD) and Kayet Bey Pump Station (KBPS), representing mixed agricultural/industrial discharge on one hand and sewage on the other. Zooplankton was simpled at four different stations from each transect (Fig. 1). Standard plankton net (mouth diameter $24 \mathrm{~cm}$, mesh size $55 \mu \mathrm{m}$ ) was used for collection and samples were preserved in $5 \%$ buffered formalin. Microzooplankton were identified and counted.

Along with zooplankton, temperature was measured and water samples were tested for salinity, chlorophyll a and dissolved oxygen (Strickland and Parsons. 1972). 

the coastal waters of Alexandria, Egypt

\section{RESULTS}

\section{Hydrographic Conditions:}

Table 1 shows the range of water quality characteristics of both sectors sampled along the coastal waters of Alexandria. El-Mex Bay (Ummum Drain Sector) seemed to be impacted by various landbased sources and man-made activities. Nearshore stations were influenced by the discharge from Ummum Drain as well as water flowing from the Western Harbor. Low salinities (reaching 9 psu during winter) were observed inshore, matching the high flow period of brackish water from Lake Mariut. Oxygen levels declined to $2.4 \mathrm{mg} / \mathrm{l}$ due to the anoxic nature of the lake water. The discharge of nutrients (nitrates and phosphates) rendered the bay an eutrophic system, with chlorophyll a levels varying between $0.2-4.4 \mu \mathrm{g} / 1$ in summer and 0.4-1.8 $\mu \mathrm{g} / \mathrm{l}$ in winter.

Kayet Bey Pump Station Sector is impacted only by sewage discharge which peaks normally during the summer season, due to residents increase using Alexandria as a summer resort. This was clearly reflected on the slight reduction in salinity (minimum 28.9 $\mathrm{psu}$ ). Receiving huge amounts of sewage discharge, renders the Kayet Bey Sector area a highly eutrophic site. This is reflected in inducing high levels of nutrients and consequently high chlorophyll a (Table 1).

\section{Distribution and diversity of tintinnids:}

During the entire study, tintinnids numerically dominated the protozoan community, comprising about (72\%) of the total Protozoa with an annual average 2078 Ind. $/ \mathrm{m}^{3}$ (Table 2). Radiolaria and Foraminifera formed the remaining $28 \%$ of protozoan population. Tintinnids were represented by 19 species, (Table 3). The most dominant ones were : Tintinnopsis beroidea, Favella ehrenbergii, Eutintinnus macilentus, T. campanula and T. cylindrica.

The two sampling transects surveyed were characterized by a untinnid-poor (UD) and a tintinnid-rich sector (KBPS).

The Tintinnids assemblages along Ummum Drain Sector constituted $62.7 \%$ of the total protozoan community with an average 1347 Ind. $/ \mathrm{m}^{3}$. Highest abundance was observed during summer (average $2447 \mathrm{Ind} . / \mathrm{m}^{3}$ ), while the minimum was recorded during winter (average $247 \mathrm{Ind} / \mathrm{m}^{3}$ ) (Table 2). Moreover, station 4 displayed 
the least density of Tintinnids (average $254 \mathrm{Ind} . \mathrm{m}^{3}$ ) during the study period. Favella ehrenbergit was the predominant species during both seasons along Unmum Drain sector (Fig. 2a). Two fresh water Tintinnids, namuly Codonella cratera and Tintinnopsis cylindrata anpeared at the rear-shore station during high flow (winter) when salinity reached 9 psu.

In the Tintinnid-rich sector (KBPS), higher values were particularly observed during summer (average $4272 \mathrm{lnd} . / \mathrm{m}^{3}$ ), while winter displayed lower densities (average $1346 \mathrm{Ind} . / \mathrm{m}^{3}$ ). Tintinnids reached their maximum density at station $7\left(9464 \mathrm{Ind} . \mathrm{m}^{3}\right)$ due to the predominance of Tintinnopsis beroidea and Favella ehrenbergii. Other tintinnid species such as Eutintinnus macilentus, Tintinnopsis campanula, T. cylindrica and Tintinnus virteus were important contributors to the tintinnids population at most stations in different seasons. The rest of tintinnids spp. persisted by low densities especially during winter (Fig. 2b).

The general composition of tintinnid assemblage did not show clear trends in association with depth. The nearshore and offshore stations were largely dominated by Tintinnopsis beroidea and Favella ehrenbergii, yet at the remaining stations relative abundances were shifted almost randomly between species (Fig. 2 a \& b).

\section{DISCUSSION}

Among the Protozoa, tintinnids were quantitatively and qualitatively, the most abundant group. They appeared in both trarsects (UD and KBPS). Several environmental conditions appear to control the regional and seasonal distribution of tintinnids including biological factors such as food supply and predation as well as the prevailing physico-chemical conditions like temperature and salinity. (Smetacek, 1981; Roberston, 1983; Sanders, 1987 and Verity, 1987). Generally, temperature is the main factor determining the distribution of tintinnids. Many authors observed that the maximum tintinnid abundance is associated with high temperature (Verity, 1987).

In the investigated area, the optimum temperature for inourishing of tintinnids ranged between $27.9-29.6{ }^{\circ} \mathrm{C}$ and the optimum salinity from 24-36.1 psu. On the other hand, low temperature (during winter) and salinity were unfavorable for the development of tintinnid assemblages. 

the coastal waters of Alexandria, Egypt

The distribution of this group was strongly correlated with those of chlorophyll a $(r=0.832)$, suggesting close trophic relationships between these groups (phytoplankton and tintinnids). However, food availability seems not only to regulate tintinnids concentrations, but also to influence the make-up of the assemblages at specific and subspecific levels. Positive correlations between lorical length and food availability have been reported by Boltovskoy et al. (1991).

Receiving huge amounts of sewage discharge, renders the Kayet Bey sector area a highly eutrophic site. This is reflected in inducing high levels of nutrients and consequently high chlorophyll a. Despite receiving considerable amounts of oxygen demanding wastes, the sector harbored the highest tintinnid densities among the study area which was dominated by Tintinnopsis beroidea. This species characterizes coastal areas with high turbulance and advective energy (Von Bodungen et al., 1986). The lorica of this species is profusely covered with agglutinated sand grains, which suggests that it benefits from the high concentrations of suspended inorganic material entrained in the water column in this shallow area.

\section{REFERENCES}

Abdel-Moati, M.A.R. (1998). Speciation of selenium at a Nile delta lagoon-SE Mediterranean Sea mixing zone. Estuar. Coast. \& Shelf Sci., 46: 621-628.

Aboul-Kassim, T.; Dowidar, N.M.; El-Nady, F.; Abdel-Moati, M.A.R. (1992). ATP and chlorophyll a biomass as eutrophication indices in one of the most polluted basins off Alexandria coastal waters, Egypt. Sci. Tot. Environ., 64: 785-798.

Boltovskoy, D.; Vivequin, S.M. and Swanberg, N.R. (1991). Vertical distribution of tintinnids and associated microplankton in the upper layer of the Barents Sea (Arctic Ocean). J. Plank. Res., 12: 403-413.

Von Bodungen,B.; Smetacek, V.S.; Tilzer, M.M. and Zeitschel, B. (1986). Primary production and sedimentation during 
sprung in the Antaretic Peninsulangion. Deep-Sca Res. 33: $177-194$.

Abdel. Aziz. WE (1, Zooplankton production along ligyptian Mediterrancus cust at Alexandria, with special reference to ife histon of one copepod species. Ph.D. Thesis. Faculty of Science. Mansoura University, 384 pp.

Abou! Erz, S.M.; Hussein, M.M. and Sallam, N.A.(1990). Effect of domestic sewage discharge on the distribution of zat anton organisms in the Eastern Harbour of Alear a (Egypt). Bull. High Instit. Pub. Health, 20( 4): 861.874.

Dowidar, N.M. and F-Mazhraby, A.M. (1970a). The neritic zoorlankton of the South eastern Mediterranean at Ale andra. I- Distribution and ecology of the zooplankton organisms with special reference to Copepoda. Bull. Inst. Oce mogr. and Fish., Egypt., 1: 225-273.

Dowidar, N.M.; Khalil, A.N.; El-Maghraby, A.M. and El-Zawawy, D.A. (1983). Zooplankton composition of the Eastern Harbour of Alexandria Egypt. Rapp. Comm. Int. Mer. Medit., 28(9):195-199.

Hussein, M.M. (1977). A study of the zooplankton in the Mediteranean waters off the Egyptian Coast during 19701971 with special reference to copepods. M. Sc. Thesis, Faculty of Science, Alexandria Univ., 228 pp.

Hussein, M.M. (1997). Distribution of zooplankton assemblages in ElMex Bay, Alexandria, Egypt. Nat. Inst. Oceanogr. and Fish.,23: 217-240.

Mazumder, A.; McQueen, D.J., Taylor, W.D.; Lean, D.R.S. and Dickman, M.D. (1990). Micro-and mesozooplankton grazing on natural picoplankton and nanoplankton in contrasting plankton communities produced by planktivore manipulation and fertilization. Arch. der Hydrobiol., 118: 257-282. 
Ecological investigation of the tintinnd communty along 171 the coastal waters of Alexandria. Egypt

Smetacek. V.(1981). The annual cycle of Prots $/ 00$ plankton in the Kat Bight. Mar. Biol., 63: 1-1!.

Robertson. I.R. (1983). Predation by estuane zomplankton on

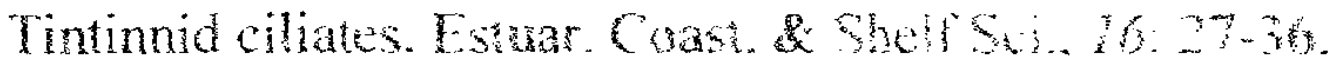

Sanders, R.W. (1987). Tintinds and other micyooplankon scasonal distribution and relationshins bo resonecs and hydrography in a mane asuary. Plank. Res. . 965-7?.

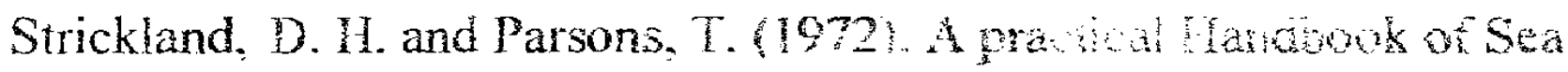

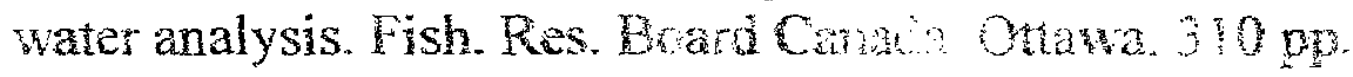

Verity, P.G. (1987). Abundance, community composition, size distribution and production rates of tintinuids in Varagansett Bay, Rhode Ishand. Estuar. Coast. \& Shelf Sci., 24: 671-690. 
Table 1. Water quality characteristics for different sectors collected along the coastal waters of Alexandria.

\begin{tabular}{|l|c|c|c|c|}
\multirow{2}{*}{ Location } & \multicolumn{2}{|c|}{ El-Mex Bey } & \multicolumn{2}{c|}{$\begin{array}{c}\text { Kayet Bey Pump } \\
\text { Ummum Drain Sector }\end{array}$} \\
\cline { 2 - 5 } & Summer & Winter & Summer & Winter \\
Parameter & 1999 & 2000 & 1999 & 2000 \\
\hline Temperature $\left({ }^{\circ} \mathrm{C}\right)$ & $27.9-28.5$ & $14.6-15.2$ & $28.4-29.6$ & $14.2-14.7$ \\
Salinity (psu) & $24-36$ & $9-27.1$ & $28.9-36.1$ & $37.2-38.9-$ \\
Dissolved oxygen $(\mathrm{mg} / \mathrm{l})$ & $3.3-5.6$ & $2.4-4.9$ & $3.0-4.1$ & $4.6-6.2$ \\
Chlorophyll a $(\mu \mathrm{g} / \mathrm{l})$ & $0.2-4.4$ & $0.4-1.8$ & $6.9-12.5$ & $4.4-8.3$ \\
\hline
\end{tabular}

Table 2. Total Tintinnids density in the investigated area

\begin{tabular}{|c|c|c|}
\hline \multirow{2}{*}{ Stations } & \multicolumn{2}{|c|}{ El-Mex Bey } \\
& Ummum Drain Sector \\
\cline { 2 - 3 } $\mathbf{1}$ & 3866 & Winter \\
$\mathbf{2}$ & 2018 & 241 \\
$\mathbf{4}$ & 3421 & 554 \\
& 482 & 167 \\
& & 26 \\
\hline Average & $\mathbf{2 4 4 7}$ & $\mathbf{2 4 7}$ \\
\hline Stations & \multicolumn{2}{|c|}{ Kayet Bey Pump Station } \\
\hline $\mathbf{5}$ & Summer & Winter \\
\hline $\mathbf{6}$ & 590 & 864 \\
$\mathbf{8}$ & 5214 & 2648 \\
& 9464 & 950 \\
& 1820 & 920 \\
\hline Average & & $\mathbf{1 3 4 6}$ \\
\hline
\end{tabular}


Ecological investigation of the Tintinnid community along 173 the coastal waters of Alexandria, Egypt

\section{Table 3. List of species of Tintinnid population}

Codonellopsis lusitanica

('. ecaudata

Eutinutinnus macilenius

Favella ehrenbergii

F. serrata

Helicostomella subulata.

Parafavella subedentata

P. denticulata

P. cylidrica

P. digitalis

Tintinnus virteus

T. latus

Tintinnopsis cylindrica

T. campanula

T. beroidea

T. minuta

T. nordiguisit

Fresh water species

Codonella cratera

Tintinnopsis cylindrata 


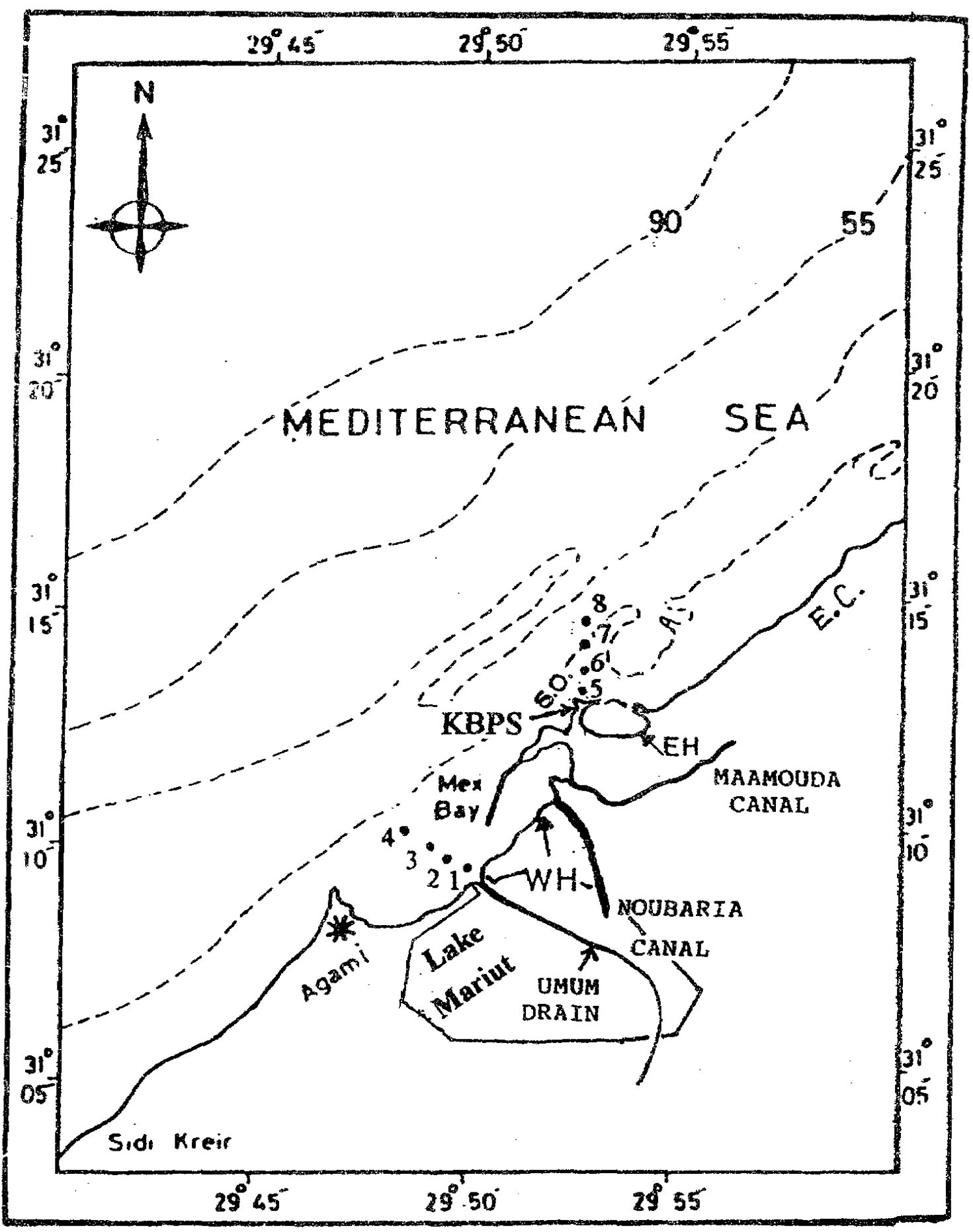

figur. Alexandria coastal area showing sampling stations. (KBPS=Kayet Bey Timp Station, WHI= Western Harbor, $\mathrm{CH}=$ Eastern Harbor). 


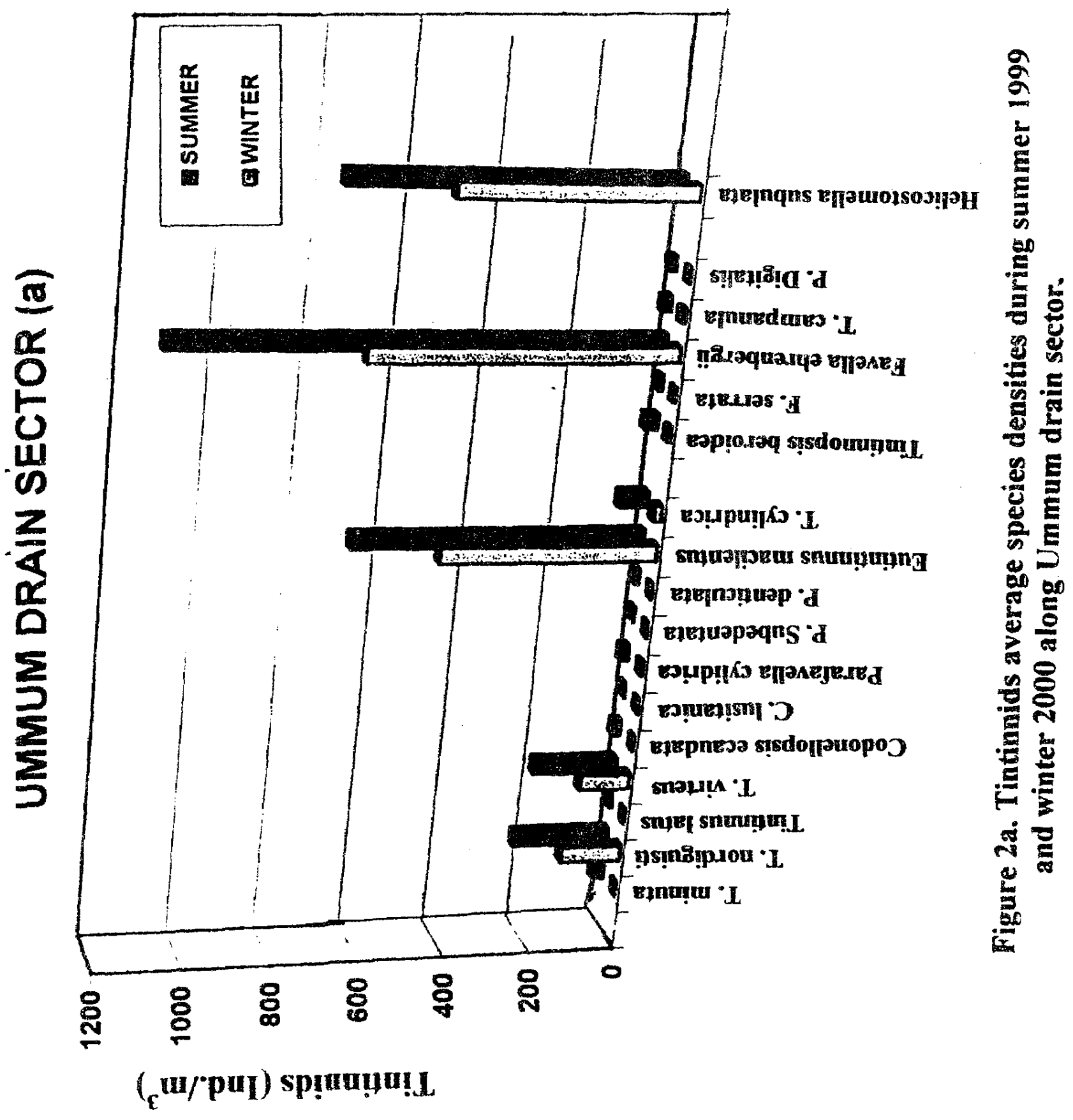




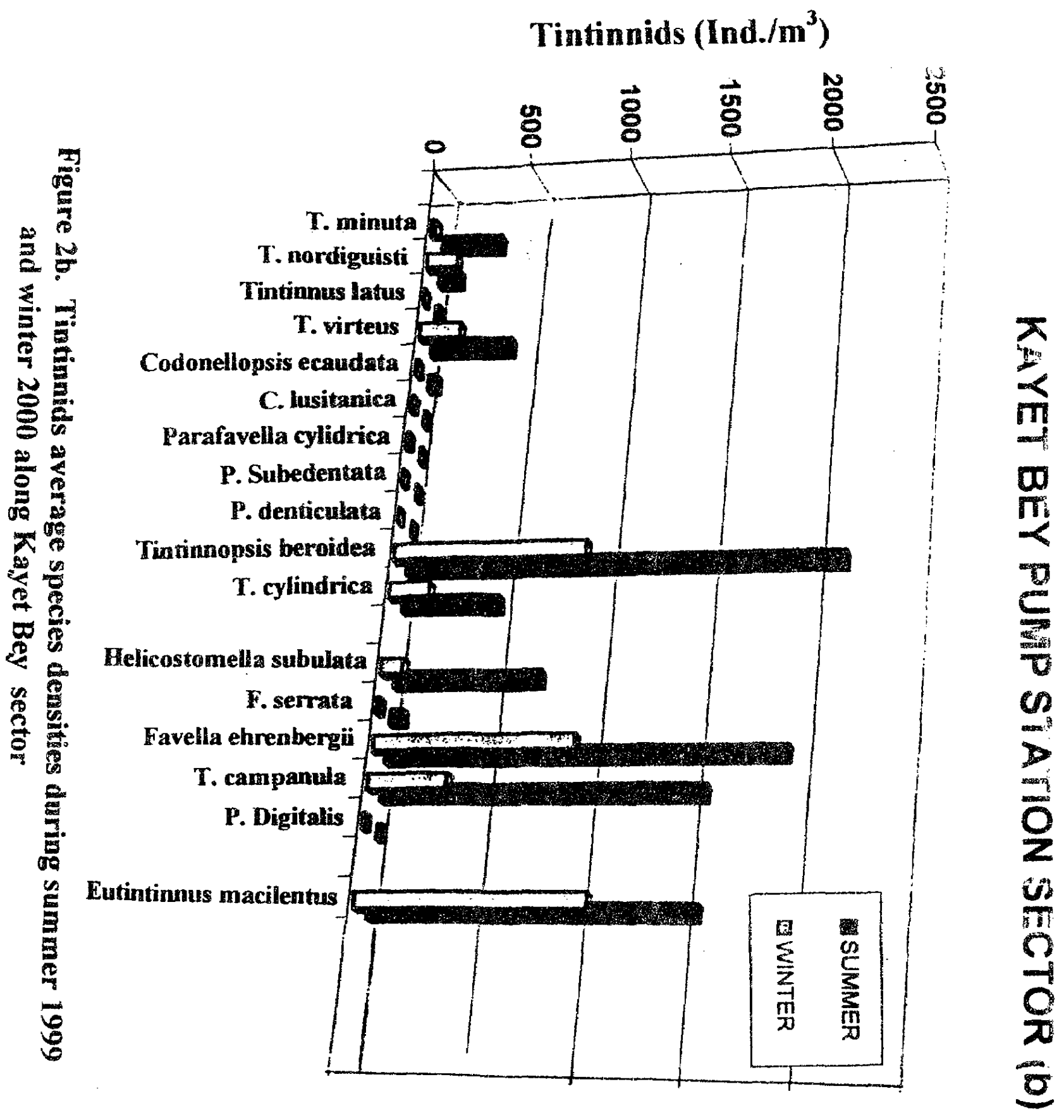

